\title{
PERBANDINGAN CAPAIAN HASIL BELAJAR KOGNITIF SISWA PADA PENERAPAN METODE PEMBELAJARAN STUDENT FACILITATOR AND EXPLAINING PADA 4 (EMPAT) KATEGORI MATA PELAJARAN PRODUKTIF
}

\author{
Tony Hartanto ${ }^{1}$, Roemintoyo ${ }^{2}$, Anis Rahmawati ${ }^{3}$ \\ hartantot@gmail.com
}

\begin{abstract}
ABSTRAK
Penelitian ini bertujuan untuk mengetahui adanya perbedaan capaian hasil belajar ranah kognitif siswa pada penerapan metode pembelajaran Student Facilitator and Explaining pada kategori mata pelajaran hitungan (mekanika teknik), kategori mata pelajaran teori (konstruksi bangunan), praktek (ukur tanah) dan gambar (gambar teknik) dan mengetahui capaian hasil belajar kognitif siswa yang paling tinggi pada penerapan metode pembelajaran Student Facilitator and Explaining diantara empat kategori mata pelajaran produktif di SMK teknik bangunan. Penelitian ini termasuk jenis kuantitatif yang digunakan untuk rancangan penelitian metode komparatif. Populasi penelitian adalah seluruh siswa kelas X Teknik Gambar Bangunan SMK tahun pelajaran 2016/2017. Teknik pengambilan sampel yang digunakan adalah teknik Purposive Sampling (Pengambilan sampel dengan sengaja), kelas X TGB B dipilih sebagai sampel. Teknik pengumpulan data digunakan tes dan dokumen sekolah. Uji hipotesis yang digunakan analisis variansi (anava). Kesimpulan dalam penelitian ini setelah dilakukan uji anava menunjukkan bahwa terdapat perbedaan yang tinggi pada capaian hasil belajar kognitif siswa pada penerapan metode pembelajaran Student Facilitator and Explaining pada kategori mata pelajaran hitungan (Mekanika Teknik), kategori mata pelajaran teori (Konstruksi Bangunan), praktek (Ukur Tanah) dan gambar (Gambar Teknik). Dapat diketahui juga pada kategori mata pelajaran produktif yang mendapat hasil belajar kognitif siswa yang paling baik pada penerapan metode pembelajaran Student Facilitator and Explaining yaitu pada kategori mata pelajaran hitungan (Mekanika Teknik) dengan melihat selisih capaian hasil belajar kognitif siswa saat pre-test dan post-test.
\end{abstract}

Kata Kunci: Model Pembelajaran Student Facilitator and Explaining, Hasil Belajar Kognitif

\footnotetext{
${ }^{1}$ Mahasiswa Program Studi Pendidikan Teknik Bangunan FKIP Universitas Sebelas Maret

${ }^{2}$ Pengajar Program Studi Pendidikan Teknik Bangunan FKIP Universitas Sebelas Maret

${ }^{3}$ Pengajar Program Studi Pendidikan Teknik Bangunan FKIP Universitas Sebelas Maret
} 


\title{
COMPARISON OF COGNITIVE STUDENT STUDY RESULTS \\ IN THE APPLICATION OF STUDENT FACILITATOR AND \\ EXPLAINING LEARNING METHOD IN FOUR (4) CATEGORIES OF \\ PRODUCTIVE SUBJECTS
}

Tony Hartanto1, Roemintoyo ${ }^{2}$, Anis Rahmawati ${ }^{3}$

hartantot@gmail.com

\begin{abstract}
This study aims to knowing there are most high cognitive students study results with the application of Student Facilitator and Explaining learning method on the category subject matter (mechanical engineering), category theory subjects (construction of buildings), practice (land surveyor) and drawing (technical drawing) and find out the most high cognitive student study results with the application of Student Facilitator and Explaining learning method among four categories of productive subjects in SMK building techniques. This research is quantitative types wich used Comparative method. The population of the research was the whole grade X TGB at SMK academic year 2016/2017. Sampling technique used Purposive Sampling, X TGB class B were selected as samples. Data collection techniques using tests and school documents. Hypothesis test used analysis of varians (anava). CThe Conclusion in this study, after test of anava shows that there are significant differences in cognitive learning student study results with the application of Student Facilitator and Explaining learning method on the category subject matter (Mechanical Engineering), category theory subjects (construction of buildings), practice (Land Surveyor) and drawing (technical drawing). Can be found also on the productive subjects category got most well cognitive student study results after the application of Student Facilitator and Explaining learning method in the categories of subject matter (Mechanical Engineering) and see the difference in cognitive student study result to the time of pre- test and post test.
\end{abstract}

Keywords: Learning Model Student Facilitator and Explaining, Cognitive Study Result 


\section{PENDAHULUAN}

Pendidikan adalah salah satu hal terpenting dalam kehidupan seseorang di dunia ini. Melalui pendidikan seseorang dapat dipandang terhormat, memiliki karir yang baik serta dapat bertingkah sesuai norma- norma yang berlaku. Dalam sebuah upaya yang dilaksanakan melalui pendidikan untuk menjadikan seseorang sebagai manusia yang berbudi pekerti dan intelektual diperlukan adanya kegiatan pembelajaran.

Guru dituntut mampu mengelola proses pembelajaran yang memberikan rangsangan kepada siswa sehingga ia mau belajar, karena siswalah subjek utama dalam belajar. Dalam beberapa kondisi saat pelaksanaan pembelajaran siswa masih kurang aktif dalam proses pembelajaran di kelas. Guru masih menjadi sentral dari proses pembelajaran di kelas, siswa pasif dan hanya mendengarkan guru menjelaskan pelajaran yang diajarkan.

Pembelajaran terpusat pada guru sampai saat ini masih menemukan beberapa kelemahan. Kelemahan tersebut dapat dilihat pada saat berlangsungnya proses pembelajaran di kelas, interaksi antara siswa dengan guru atau siswa dengan siswa jarang terjadi serta penggunaan alat peraga dalam kegiatan belajar mengajar di kelas masih kurang. Siswa kurang terampil menjawab pertanyaan atau bertanya tentang konsep yang diajarkan. Siswa kurang bisa bekerja dalam kelompok diskusi dan pemecahan masalah yang diberikan. Mereka cenderung belajar sendiri-sendiri. Pengetahuan yang didapat bukan dibangun sendiri secara bertahap oleh siswa atas dasar pemahaman sendiri. Karena siswa jarang menemukan jawaban atas permasalahan atau konsep yang dipelajari. Dari hasil observasi yang dilakukan pada empat kategori mata pelajaran produktif di kelas X TGB B angkatan 2016 banyak siswa yang belum tuntas pada keempat kategori mata pelajaran produktif SMK teknik bangunan.

Dengan rincian pada kategori mata pelajaran hitungan (Mekanika Teknik) terdapat 8 siswa dinyatakan tuntas dan 26 siswa dinyatakan tidak tuntas atau $23.52 \%$ sis wa tuntas dan $76.47 \%$ siswa tidak tuntas, pada kategori mata pelajaran teori (Konstruksi Bangunan) terdapat 14 siswa dinyatakan tuntas dan 20 siswa dinyatakan tidak tuntas atau $41,18 \%$ siswa tuntas dan $58.82 \%$ siswa tidak tuntas, pada kategori mata pelajaran praktek (Ukur Tanah) terdapat 11 siswa dinyatakan tuntas dan 23 siswa dinyatakan tidak tuntas atau $32.35 \%$ siswa tuntas dan $67.65 \%$ siswa tidak tuntas serta pada kategori mata pelajaran gambar (Gambar Teknik) terdapat 10 siswa dinyatakan tuntas dan 24 siswa dinyatakan tidak tuntas atau $29.41 \%$ siswa tuntas dan $70.59 \%$ siswa tidak tuntas. Siswa yang dinyatakan tuntas harus memenuhi nilai KKM dengan nilai $>75$. Dari data tersebut dapat dilihat hasil belajar siswa masih kurang memuaskan.

Permasalahan tersebut perlu diatasi menggunakan pembelajaran dengan metode yang membuat siswa dapat berperan aktif dan 
meningkatkan kemampuan ranah kognitif siswa. Peran guru sangat penting untuk menciptakan suasana pembelajaran yang baru dan membuat siswa meningkatkan kemampuan ranah kognitif. Agar hasil belajar tercapai dengan baik, guru harus mampu memilih metode pembelajaran yang sesuai dengan materi pelajaran.

Metode pembelajaran dimaksudkan untuk mengoptimalkan penggunaan semua potensi yang dimiliki Siswa, seperti yang dikemukakan oleh Sani (2013: 158) bahwa metode pembelajaran merupakan langkah operasional dari strategi pembelajaran yang dipilih untuk mencapai tujuan pembelajaran. Metode pembelajaran juga dimaksudkan untuk menjaga perhatian siswa agar tetap tertuju pada proses pembelajaran. Belajar aktif pada dasarnya berusaha untuk memperkuat dan memperlancar stimulus dan respon Siswa dalam pembelajaran, sehingga pembelajaran menjadi menyenangkan.

Student Facilitator and Explaining merupakan salah satu dari pembelajaran kooperatif dengan menggunakan kelompok-kelompok kecil dengan jumlah anggota tiap kelompok 4-5 orang siswa secara heterogen. Tipe ini memberikan kesempatan siswa atau Siswa untuk mempresentasikan ide, pendapat, atau gagasan pada rekan peserta lainnya.

Metode pembelajaran Student Facilitator and Explaining terpusat pada siswa sehingga siswa dapat mengikuti pelajaran dengan aktif.
Metode pembelajaran Student Facilitator and Explaining didasarkan pada keterampilan siswa menemukan informasi dan mengemukakan pendapatnya di depan kelas. Setelah itu guru bersama sama dengan siswa menyimpulkan tentang beberapa pendapat yang berbeda dari siswa yang mengemukakan pendapatnya di depan kelas. Dengan demikian semua siswa dapat memiliki kesepahaman tentang materi peembelajaran yang disampaikan oleh guru sebelumnya.

Terkait dengan pengertian tipe pembelajaran Student Facilitator And Explaining, Sims dan Demediuk (1995) dalam artikelnya menjelaskan bahwa guru akan menyiapkan calon fasilitator yang diambil secara acak untuk dipersiapkan secara efektif sebelum memimpin diskusi. Pengambilan secara acak dapat diberitahukan atau tidak siapakah yang akan membawakan diskusi atau menjadi presenter (discussion leaders) dengan siswa lain aktif dan partisipasif. Metode tersebut diidentifikasi dengan melihat pola interaksi antar guru dengan Siswa. Molenda (Sani, 2013:159) mencoba mengelompokan metode instruksional dengan melihat pola interaksi antara guru, Siswa, dan sumber belajar. Berdasarkan interaksi tersebut, metode instruksional dikelompokan sebagai berikut :

a. Tutorial: terjadinya interaksi dua arah antara tutor dan Siswa.

b. Ceramah/ kuliah: informasi satu arah dari sumber belajar (guru) pada Siswa. 
c. Diskusi: terjadi interaksi dua arah antara Siswa.

d. Kegiatan labolatorium: Siswa berinteraksi dengan sumber berupa alat, bahan, dan kejadian.

e. Belajar mandiri: Siswa berinteraksi dengan sumber belajar yang belum dipelajari atau diolah.

f. Latihan: Siswa menggunakan keterampilannya secara berulang.

Dengan demikian siswa akan termotivasi dan mempersiapkan dengan membaca dan memahami materi terlebih dahulu Selain hal tersebut, Sims dan Demediuk (1995) juga mengatakan siswa dijadikan sebagai fasilitator yaitu dengan mencalonkan siswa sebagai fasilitator akan membuat siswa lebih percaya diri dan mempersiapkan materi serta mendalaminya dengan tujuan untuk meningkatkan kualitas pembelajaranFasilitator diberi petunjuk, isyarat dan pendekatan dalam menjawab pertanyaanpertanyaan yang akan disampaikan teman- nya. Fasilitator bukan hanya bertugas sebagai penjawab pertanyaan saja, namun fasilitator disini lebih kepada proses penyampaian materi dan mengatur jalannya diskusi atau proses pembelajaran.

Disini tugas guru meyakinkan siswa lain tentang yang disampaikan fasilitator dengan memberikan penguatan terhadap pendekatan yang disampaikan fasilitator dan mengamati sekaligus sebagai pengarah proses pembelajaran agar tidak melenceng dari tujuan pembelajaran itu sendiriAgar proses pembelajaran dapat berjalan dengan baik dan terstruktur, Suprijono
(2009) menyebutkan langkahlangkah dari pelaksanaan Student Facilitator And Explaining sebagai berikut:

a) Guru menyampaikan kompetensi yang ingin dicapai

b) Guru mendemonstrasikan/ menyajikan materi

c) Memberikan kesempatan siswa untuk menjelaskan kepada siswa lainnya misalnya melalui bagan/ peta konsep

d) Guru menyimpulkan ide/ pendapat dari siswa, guru menerangkan semua materi yang disajikan saat itu

e) Penutup.

$$
\text { Prasetiya dalam Inayatul }
$$
(2010) melaporkan bahwa metode pembelajaran Student Facilitator And Explaining memiliki kelebihan antara lain dapat mendorong tumbuh dan kembangnya potensi berpikir kritis siswa secara optimal, melatih siswa aktif, kreatif dan menghadapi setiap permasalahan, mendorong tumbuhnya tenggang rasa atau mendengarkan dan menghargai pendapat orang lain, mendorong tumbuhnya sikap demonstrasi, melatih siswa untuk meningkatkan kemampuan saling bertukar pendapat secara objektif, rasional guna menemukan suatu kebenaran dalam kerja sama anggota kelompok, mendorong tumbuhnya keberanian mengutamakan pendapat siswa secara terbuka, melatih siswa untuk dapat mandiri dalam menghadapi setiap masalah, melatih kepemimpinan siswa serta memperluas wawasan siswa melalui kegiatan saling bertukar informasi pendapat dan pengalaman mereka. 
Beberapa kelebihan yang sudah dipaparkan memiliki satu persamaan yaitu Student Facilitator And Explaining memudahkan siswa untuk meningkatkan kreatifitas dan prestasi belajar yang selama ini prestasi belajar siswa belum mencapai keberhasilan yang maksimal. Metode pembelajaran Student Facilitator and Explaining juga memiliki beberapa kelemahan yaitu siswa yang malu tidak mau mendemonstrasikan apa yang diperintahkan oleh guru kepadanya atau banyak siswa yang kurang aktif, tidak semua siswa memiliki kesempatan yang sama untuk melakukannya (menjelaskan kembali kepada teman-temannya karena keterbatasan waktu pembelajaran), adanya pendapat yang sama sehingga hanya sebagian saja yang terampil dan tidak mudah bagi siswa untuk membuat peta konsep atau menerangkan materi ajar secara ringkas.

Tujuan aspek kognitif berorientasi pada kemampuan berfikir yang mencakup kemampuan intelektual yang lebih sederhana, yaitu mengingat, sampai pada kemampuan memecahkan masalah yang menuntut siswa untuk menghubungakan dan menggabungkan beberapa ide, gagasan, metode atau prosedur yang dipelajari untuk memecahkan masalah tersebut. Dengan demikian aspek kognitif adalah subtaksonomi yang mengungkapkan tentang kegiatan mental yang sering berawal dari tingkat pengetahuan sampai ke tingkat yang paling tinggi yaitu evaluasi.
Penggunaan

metode pembelajaran Student Facilitator and Explaining menjadikan siswa berperan aktif dan melatih berkomunikasi untuk menyampaikan pendapat tentang materi pelajaran yang dia terima untuk dibagikan kepada teman sekelas lainnya. Metode pembelajaran Student Facilitator and Explaining ini bisa diterapkan di semua jenjang pendidikan dan semua mata pelajaran. Dalam pembelajaran di sekolah tingkat Sekolah Menengah Kejuruan (SMK) teknik bangunan ada empat kategori mata pelajaran produktif yang dipelajari oleh siswa SMK Teknik Bangunan yaitu hitungan, teori, gambar dan praktek. Dari masing-masing kategori itu metode yang dilaksanakan oleh tiap guru pada tiap mata pelajaran pun berbeda. Siswa memiliki ketertarikan yang berbeda dari masing-masing kategori mata pelajaran produktif tersebut dan akan mempengaruhi hasil belajar ranah kognitif setiap siswa.

Tujuan penelitian ini adalah mengetahui adanya perbedaan yang lebih tinggi pada capaian hasil belajar ranah kognitif siswa dengan penerapan metode pembelajaran Student Facilitator and Explaining pada kategori mata pelajaran hitungan (Mekanika Teknik), kategori mata pelajaran teori (Konstruksi Bangunan), praktek (Ukur Tanah) dan gambar (Gambar Teknik) dan mengetahui hasil belajar kognitif siswa pada salah satu kategori mata pelajaran produktif di SMK teknik bangunan dengan penerapan metode pembelajaran Student Facilitator and Explaining mendapatkan selisih capaian hasil 
belajar kognitif siswa yang lebih tinggi antara pre-test dan post-test dibandingkan dengan ketiga kategori mata pelajaran produktif di SMK teknik bangunan yang lain.

\section{METODE PENELITIAN}

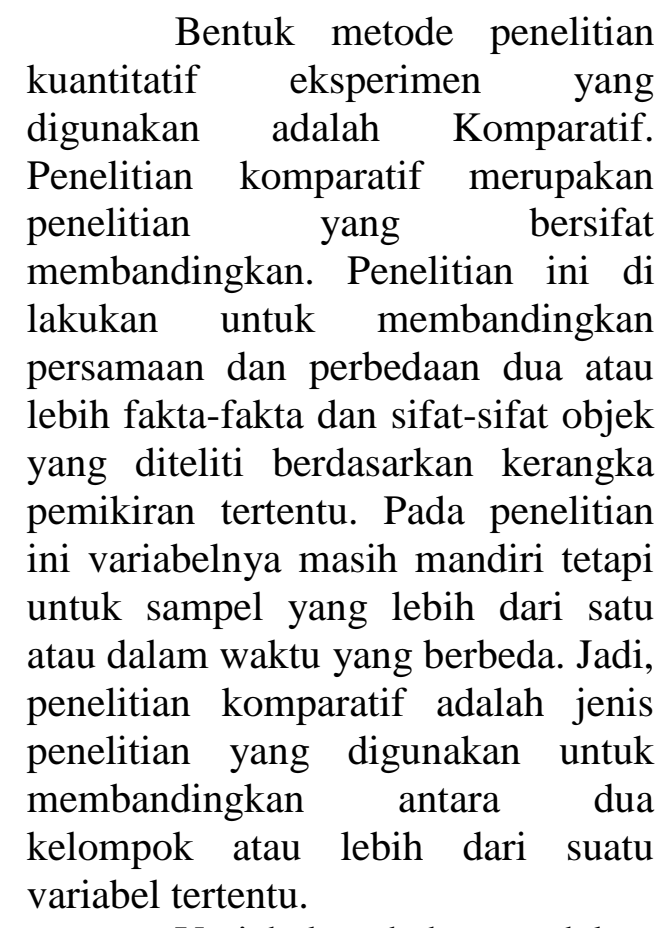

Variabel bebas dalam penelitian ini adalah empat kategori mata pelajaran produktif di SMK Teknik Bangunan sedangkan variabel terikat dalam penelitian ini adalah hasil belajar aspek kognitif siswa di empat kategori mata pelajaran dengan metode pembelajaran kooperatif Student Facilitator and Explaining. Hasil belajar keempat mata pelajaran tersebut diukur dengan menggunakan alat ukur yang sama, yaitu soal tes hasil belajar.

Populasi dalam penelitian ini adalah seluruh siswa kelas $\mathrm{X}$ TGB yang berjumlah dua kelas, yaitu kelas X TGB A dengan jumlah 35 siswa dan kelas $\mathrm{X}$ TGB $\mathrm{B}$ dengan jumlah 34 siswa. Sehingga jumlah populasi pada penelitian ini ada 69 siswa. Yang menjadi sampel pada penelitian ini adalah kelas X TGB B tahun ajaran 2016/2017. Dalam penelitian ini, teknik sampling yang digunakan adalah purposive sampling. Purposive sampling adalah pengambilan sampel yang dilakukan dengan memilih secara sengaja menyesuaikan dengan tujuan penelitian. Dengan menggunakan purposive sampling diharapkan kriteria sampel yang diperoleh benar-benar sesuai dengan penelitian yang akan dilakukan

$\begin{array}{lcr} & \text { Penelitian ini } & \text { digunakan } \\ \text { beberapa } & \text { teknik } & \text { untuk } \\ \text { mempermudah } & \text { memperoleh } & \text { data }\end{array}$
yang diperlukan yaitu dokumentasi foto dan tes tertulis. Uji coba dilakukan untuk mengetahui validitas, realibilitas, ingkat kesukaran dan daya beda butir soal. Setelah diketahui validitas, realibilitas tingkat kesukaran dan daya beda kemudian dipilih butir soal yang memenuhi kualifikasi. Analisis data pada bagian ini bertujuan untuk mengkaji kebenaran hipotesis yang diajukan. Analisa digunakan untuk mengolah data adalah uji normalitas data menggunakan chi-kuadrat, uji homogenitas menggunakan uji $\mathrm{F}$, uji independensi dan uji hipotesis menggunakan analisis varian (anava) satu jalur. Uji persyaratan analisis dilakukan dengan maksud agar kesimpulan yang diambil dapat dipertanggungjawabkan. 


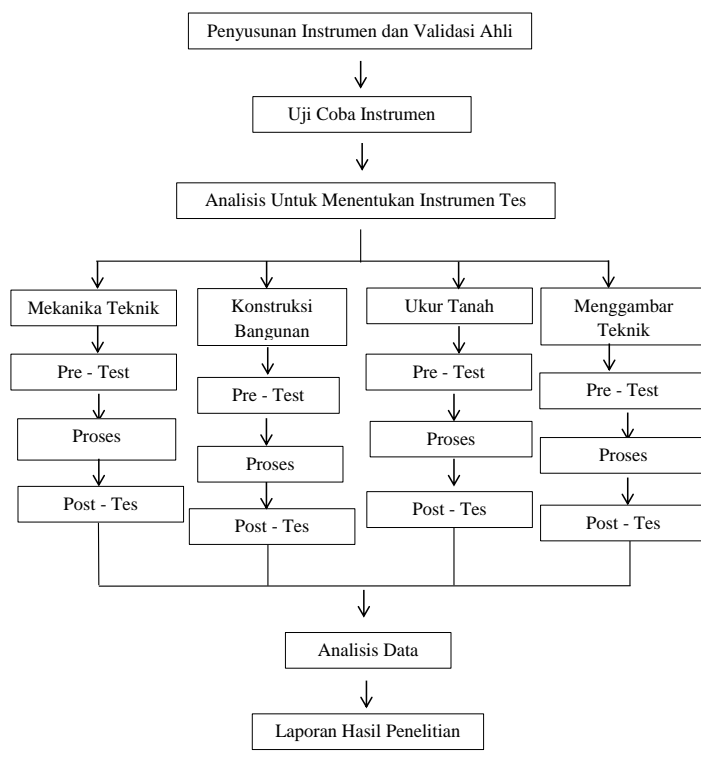

Gambar 1. Prosedur penelitian

\section{HASIL PENELITIAN}

\section{Deskripsi Data}

Penelitian ini merupakan jenis penelitian komparatif. Penelitian ini yaitu dengan cara peneliti melakukan perlakuan terhadap variabel bebas dan mengamati perubahan yang terjadi pada variabel terikat setelah diberikan perlakuan. Variabel bebas dalam penelitian ini adalah empat kategori mata pelajaran produktif di SMK Teknik Bangunan sedangkan variabel terikat dalam penelitian ini adalah hasil belajar ranah kognitif siswa di empat kategori mata pelajaran dengan metode pembelajaran Student Facilitator and Explaining.

Sampel pada penelitian ini terdiri dari mata pelajaran Mekanika Teknik, Konstruksi Bangunan, Ukur Tanah dan Gambar Teknik. Hasil belajar keempat mata pelajaran tersebut diukur dengan menggunakan alat ukur yang sama, yaitu soal tes hasil belajar ranah kognitif siswa. Ada 69 siswa yang terlibat pada penelitian ini yaitu 35 siswa kelas X TGB A untuk uji coba soal dan 34 siswa kelas TGB B untuk penelitian. Teknik pengumpulan data pada variabel empat kategori mata pelajaran produktif di SMK Teknik Bangunan digunakan tes dalam bentuk obyektif, untuk mengetahui beberapa aspek kelayakannya, sebelum soal digunakan terlebih dahulu diadakan uji coba soal. Uji coba soal dilaksanakan dikelas X TGB A dengan jumlah yang mengikuti 35 siswa, hal ini dikarenakan kelas tersebut sudah pernah mendapatkan materi soal yang akan diuji cobakan.

Sebanyak 15 butir soal yang diuji cobakan pada empat kategori mata pelajaran, pada mata pelajaran ukur tanah diperoleh 7 butir soal yang valid dan 8 butir soal tidak valid, pada mata pelajaran mekanika teknik diperoleh 7 butir soal yang valid dan 8 butir soal tidak valid, pada mata pelajaran gambar teknik diperoleh 8 butir soal yang valid dan 7 butir soal tidak valid, pada mata pelajaran konstruksi bangunan diperoleh 8 butir soal yang valid dan 7 butir soal tidak valid, jadi soal yang digunakan hanya 5 butir soal untuk pre-test dan 5 butir soal untuk post-test pada empat kategori mata pelajaran. Berdasarkan data yang diperoleh dalam penelitian ini, maka dapat dibuat deskripsi data khusus sebagai berikut: 


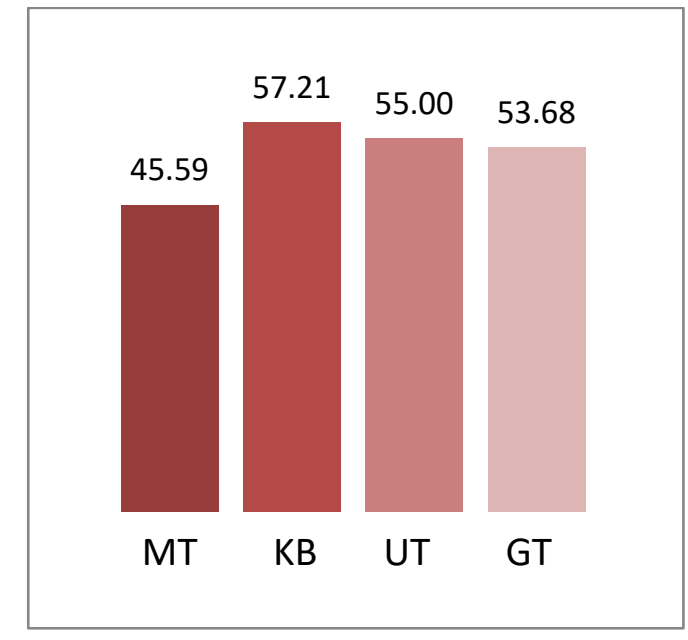

Gambar 2. Diagram Batang Perbandingan Nilai Rata-Rata Hasil Belajar Pre-Test

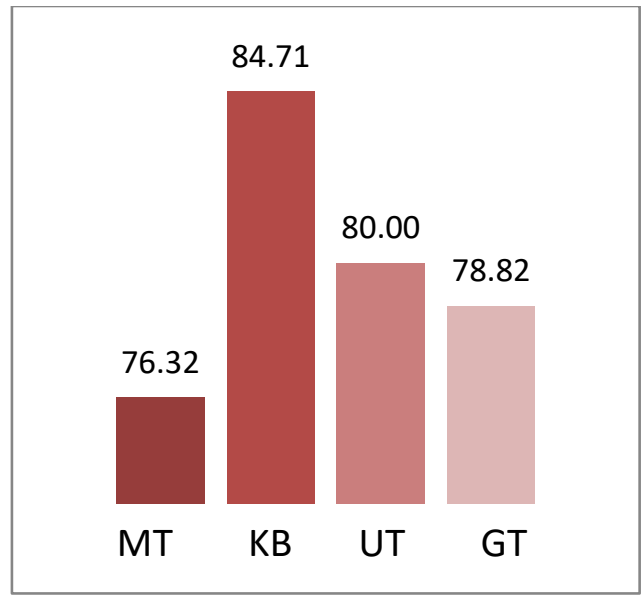

Gambar 3. Diagram Batang Perbandingan Nilai Rata-Rata Hasil Belajar Post-Test

2. Hasil Uji Persyaratan Analisis a. Uji Normalitas

Uji Normalitas yang digunakan adalah uji chi kuadrat. Data yang digunakan untuk uji normalitas adalah data hasil belajar pre-test dan post-test ranah kognitif siswa kelas X TGB B pada empat kategori mata pelajaran produktif SMK Teknik
Bangunan dengan jumlah responden 34 siswa. Data diambil sebelum dan setelah diberi perlakuan dengan metode pembelajaran kooperatif student facilitator and explaining. Populasi dapat dikatakan berdistribusi normal jika $\chi_{\text {hitung }}^{2} \leq \chi^{2}{ }_{\text {tabel }}$. Secara ringkas pada tabel berikut:

\begin{tabular}{cccl}
\hline $\begin{array}{c}\text { Mata } \\
\text { Pelajaran }\end{array}$ & $\begin{array}{c}\text { Harga } \\
\left(\chi^{2}\right) \\
\text { Hitung }\end{array}$ & $\begin{array}{c}\text { Harga } \\
\left(\chi^{2}\right) \\
\text { Tabel }\end{array}$ & $\begin{array}{c}\text { Kesim } \\
\text { pulan }\end{array}$ \\
\hline $\begin{array}{c}\text { Mekanika } \\
\text { Teknik }\end{array}$ & $\mathbf{1 0 . 0 8}$ & $\mathbf{1 1 . 0 7}$ & Normal \\
& & &
\end{tabular}

\section{Konst. $\quad 10.76 \quad 11.07 \quad$ Normal Bangunan}

\section{$\begin{array}{llll}\text { Ukur } & 10.89 & 11.07 & \text { Normal }\end{array}$} Tanah

\begin{tabular}{llll}
$\begin{array}{l}\text { Gambar } \\
\text { Teknik }\end{array}$ & 9.86 & $\mathbf{1 1 . 0 7}$ & Normal \\
\hline $\begin{array}{l}\text { Tabel 1. } \\
\text { Normalitas }\end{array}$ & Perbandingan & Uji \\
\hline
\end{tabular}

b. Uji Homogenitas Hasil Belajar Ranah Kognitif Siswa

\begin{tabular}{cccc}
\hline $\begin{array}{c}\text { Mata } \\
\text { Pelajaran }\end{array}$ & $\begin{array}{c}\text { Harga } \\
\left(\chi^{2}\right) \\
\text { Hitung }\end{array}$ & $\begin{array}{c}\text { Harga } \\
\left(\chi^{2}\right) \\
\text { Tabel }\end{array}$ & $\begin{array}{c}\text { Kesim } \\
\text { pulan }\end{array}$ \\
\hline $\begin{array}{c}\text { Mekanika } \\
\text { Teknik }\end{array}$ & $\mathbf{1 . 0 7}$ & $\mathbf{1 . 7 6}$ & Homogen \\
$\begin{array}{c}\text { Konst. } \\
\text { Bangunan }\end{array}$ & 1.51 & 1.76 & Homogen \\
$\begin{array}{c}\text { Ukur } \\
\text { Tanah }\end{array}$ & 1.11 & 1.76 & Homogen \\
$\begin{array}{c}\text { Gambar } \\
\text { Teknik }\end{array}$ & 1.05 & 1.76 & Homogen \\
\hline $\begin{array}{l}\text { Tabel 2. } \\
\text { Homogenitas }\end{array}$ & & & \\
\hline Perbandingan & Uji
\end{tabular}


c. Uji Independensi

Uji Independensi menggunakan uji $\chi^{2}$, untuk mengetahui apakah adanya keterkaitan antara hasil belajar ranah kognitif siswa pre-test dan post-test dengan empat kategori mata pelajaran produktif SMK teknik. Uji hipotesis sebagai berikut:

$\mathrm{H}_{0}$ : Rerata hasil belajar kognitif siswa independen terhadap empat kategori mata pelajaran produktif SMK teknik bangunan. $\mathrm{H}_{1}$ : Rerata hasil belajar kognitif siswa tidak independen terhadap empat kategori mata pelajaran produktif SMK teknik bangunan. Dengan kriteria uji sebagai berikut:

$\mathrm{H}_{0}$ diterima jika:

$\chi_{\text {hitung }}^{2}<\chi^{2}$ tabel

$\mathrm{H}_{0}$ ditolak jika :

$\chi_{\text {hitung }}^{2}>\chi_{\text {tabel }}^{2}$

Hasil pengujian diperoleh $\chi_{\text {hitung sebesar } 0.387<}$ $\chi_{\text {tabel }}{ }^{2}$ pada taraf signifikansi $5 \%$ sebesar $=7.815$. Hasil pengujian menunjukan bahwa $\mathrm{H}_{0}$ diterima, rerata hasil belajar kognitif siswa independen terhadap empat kategori mata pelajaran produktif SMK teknik bangunan.

Setelah syarat terpenuhi, maka dapat dilakukan uji anava. Pada penelitian ini yang digunakan adalah anava satu jalan dengan sel sama dengan taraf signifikansi $5 \%$. Data yang digunakan adalah nilai posttest dari keempat kategori mata pelajaran produktif SMK teknik bangunan. Dan rangkumannya ditunjukan pada Tabel berikut :

\begin{tabular}{lcccc}
\hline Sumber Data & JK & $\mathbf{F}_{\text {obs }}$ & $\mathbf{F}_{\text {tabel }}$ & Kep. Uji \\
\hline Kognitif & 1259,375 & 7,955 & 2,6 & $\mathrm{H}_{0}$ \\
& & & & ditolak \\
Galat & 6965,441 & - & - & \\
\hline Total & $\mathbf{8 2 2 4 , 8 1 6}$ & - & - &
\end{tabular}

Tabel 3. Rangkuman Anava Satu Jalan Dengan Sel Sama

Hasil yang diperoleh dari perhitungan anava satu jalan dengan sel sama terhadap kemampuan ranah kognitif siswa pada keempat kategori mata pelajaran siswa. Pada keempat kategori mata pelajaran diperoleh hasil $7,955>2,6$. hal tersebut menunjukkan bahwa $\mathrm{H}_{0}$ ditolak. Kesimpulan dari perhitungan anava satu jalan dengan sel sama pada penelitian ini adalah terdapat adanya perbedaan pada hasil belajar ranah kognitif siswa pada keempat kategori mata pelajaran yang berbeda yaitu: Mekanika Teknik (Hitungan), Konstruksi Bangunan (Teori), Ukur Tanah (Praktik) dan Gambar Teknik (Gambar) dengan penerapan metode pembelajaran kooperatif Student Facilitator and Explaining.

\section{PEMBAHASAN}

Hasil dari perhitungan yang diperoleh anava satu jalan dengan sel sama $\mathrm{F}_{\text {obs }}=7,955$ dan DK $=\{\mathrm{F} \mid \mathrm{F}>2,6\}$ maka $\mathrm{H}_{0}$ ditolak yang menunjukkan bahwa terdapat perbedaan yang signifikan pada hasil belajar ranah kognitif siswa dengan penerapan metode pembelajaran kooperatif Student Facilitator and Explaining pada kategori mata pelajaran hitungan (Mekanika teknik), kategori mata pelajaran teori (Konstruksi bangunan), praktek 
(Ukur tanah) dan gambar (Gambar teknik).

Hasil uji anava sesuai dengan hipotesis yang menyebutkan bahwa terdapat perbedaan yang signifikan pada hasil belajar ranah kognitif siswa dengan penerapan metode pembelajaran kooperatif Student Facilitator and Explaining pada keempat kategori mata pelajaran produtif Teknik Bangunan. Dan setelah uji anava diperoleh hasil sebagai berikut:

1. Penerapan metode pembelajaran kooperatif Student Facilitator And Explaining pada kategori mata pelajaran hitungan (Mekanika Teknik).

Setelah penerapan metode pembelajaran kooperatif Student Facilitator And Explaining, ada perbedaan yang signifikan dari hasil belajar kognitif siswa. Hasil ini bisa dilihat pada histogram berikut :

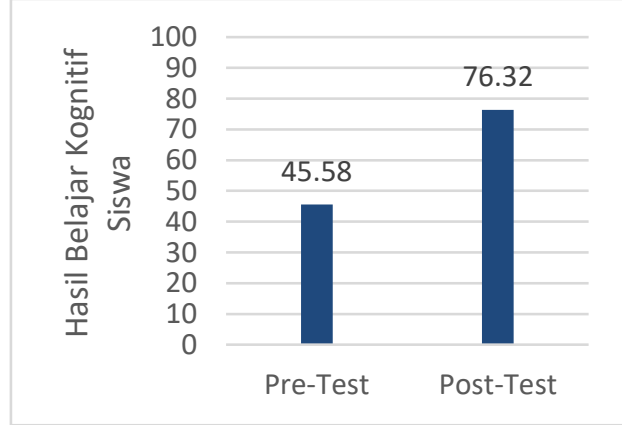

Gambar 4. Histogram Perbandingan Hasil Belajar PreTest dan Post-Test Ranah Kognitif Siswa Pada Mata Pelajaran Mekanika Teknik

Adanya perbedaan yang signifikan dari hasil belajar kognitif siswa pada kategori mata pelajaran hitungan (Mekanika Teknik) setelah diterapkan metode pembelajaran kooperatif Student Facilitator And Explaining terjadi karena dalam proses pembelajaran setiap kelompok berdiskusi dan mengemukakan pendapatnya di depan kelas tentang materi yang mereka diskusikan dengan kelompoknya. Apabila ada kelompok lain yang memiliki pendapat berbeda akan didiskusikan bersama dengan guru mata pelajaran untuk mendapatkan hasil diskusi yang tepat sesuai dengan tujuan pembelajaran.

Siswa dalam mengemukakan pendapat juga menjelaskan tentang materi hitungan dan memecahkan masalah hitungan di depan kelas. Kegiatan tersebut menuntut siswa untuk memahami materi tersebut sebagai tanggung jawab untuk menjelaskan kepada teman sekelasnya. Dengan demikian selain mampu memperbaiki hasil belajar kognitif siswa penerapan metode pembelajaran kooperatif Student Facilitator And Explaining pada kategori mata pelajaran hitungan (Mekanika Teknik) juga memberikan kepercayaan diri siswa dalam berpendapat, saling menghargai pendapat sesama siswa dan tanggung jawab dalam menjelaskan hasil diskusi kelompoknya.

2. Penerapan metode pembelajaran kooperatif Student Facilitator And Explaining pada kategori mata pelajaran teori (Konstruksi Bangunan).

Setelah penerapan metode pembelajaran kooperatif Student Facilitator And Explaining, ada perbedaan yang signifikan dari hasil belajar 
kognitif siswa. Hasil ini bisa dilihat pada histogram berikut :

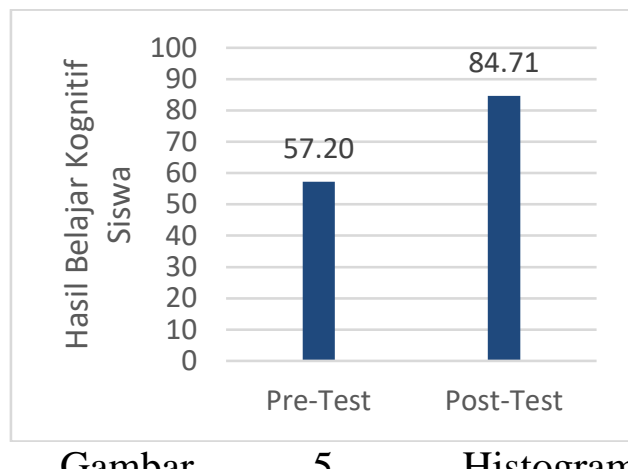

Gambar 5. Histogram

Perbandingan Hasil Belajar Pre-

Test dan Post-Test Ranah Kognitif

Siswa Pada Mata Pelajaran

Konstruksi Bangunan

Adanya perbedaan yang signifikan dari hasil belajar kognitif siswa pada kategori mata pelajaran teori (Konstruksi Bangunan) setelah diterapkan metode pembelajaran kooperatif Student Facilitator And Explaining terjadi karena dalam proses pembelajaran setiap kelompok berdiskusi dan mengemukakan pendapatnya di depan kelas tentang materi yang mereka diskusikan dengan kelompoknya. Apabila ada kelompok lain yang memiliki pendapat berbeda akan didiskusikan bersama dengan guru mata pelajaran untuk mendapatkan hasil diskusi yang tepat sesuai dengan tujuan pembelajaran.

Siswa dalam mengemukakan pendapat juga menjelaskan tentang materi teori di depan kelas menuntut siswa untuk memahami materi tersebut sebagai tanggung jawab untuk menjelaskan kepada teman sekelasnya. Dengan demikian selain mampu memperbaiki hasil belajar kognitif siswa penerapan metode pembelajaran kooperatif Student Facilitator And Explaining pada kategori mata pelajaran teori (Konstruksi Bangunan) juga memberikan kepercayaan diri siswa dalam berpendapat, saling menghargai pendapat sesama siswa dan tanggung jawab dalam menjelaskan hasil diskusi kelompoknya.

3. Penerapan metode pembelajaran kooperatif Student Facilitator And Explaining pada kategori mata pelajaran praktik (Ukur Tanah).

Setelah penerapan metode pembelajaran kooperatif Student Facilitator And Explaining, ada perbedaan yang signifikan dari hasil belajar kognitif siswa. Hasil ini bisa dilihat pada histogram berikut :

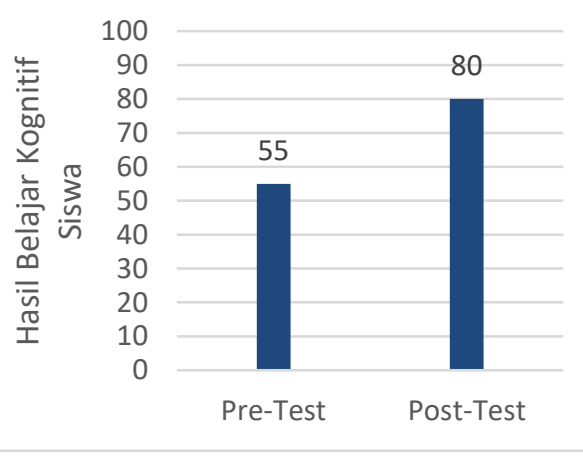

Gambar $6 . \quad$ Histogram Perbandingan Hasil Belajar PreTest dan Post-Test Ranah Kognitif Siswa Pada Mata Pelajaran Ukur Tanah

Adanya perbedaan yang signifikan dari hasil belajar kognitif siswa pada kategori mata pelajaran praktik (Ukur Tanah) setelah diterapkan metode pembelajaran kooperatif Student Facilitator And Explaining terjadi 
karena dalam proses pembelajaran setiap kelompok berdiskusi dan mengemukakan pendapatnya di depan kelas tentang materi yang mereka diskusikan dengan kelompoknya. Apabila ada kelompok lain yang memiliki pendapat berbeda akan didiskusikan bersama dengan guru mata pelajaran untuk mendapatkan hasil diskusi yang tepat sesuai dengan tujuan pembelajaran.

$$
\text { Siswa dalam }
$$
mengemukakan pendapat juga menjelaskan tentang materi dan mempraktikan cara penggunaan peralatan ukur tanah seperti bak ukur, kompas dll di depan kelas. Kegiatan tersebut menuntut siswa untuk memahami materi tersebut sebagai tanggung jawab untuk menjelaskan kepada teman sekelasnya. Dengan demikian selain mampu memperbaiki hasil belajar kognitif siswa penerapan metode pembelajaran kooperatif Student Facilitator And Explaining pada kategori mata pelajaran praktik (Ukur Tanah). juga memberikan kepercayaan diri siswa dalam berpendapat, saling menghargai pendapat sesama siswa dan tanggung jawab dalam menjelaskan hasil diskusi kelompoknya.

4. Penerapan metode pembelajaran kooperatif Student Facilitator And Explaining pada kategori mata pelajaran gambar (Gambar Teknik).

Setelah penerapan metode pembelajaran kooperatif Student Facilitator And Explaining, ada perbedaan yang signifikan dari hasil belajar kognitif siswa. Hasil ini bisa dilihat pada histogram berikut :

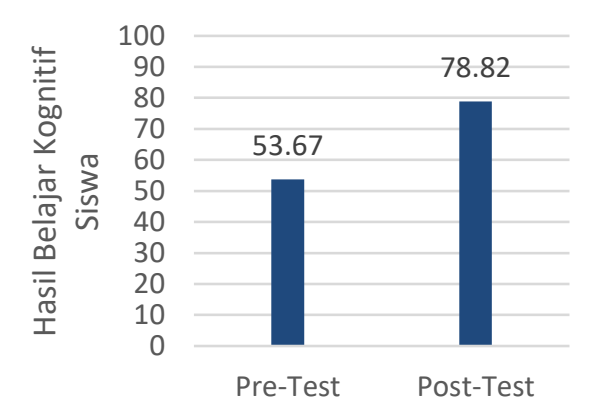

Gambar $7 . \quad$ Histogram Perbandingan Hasil Belajar PreTest dan Post-Test Ranah Kognitif Siswa Pada Mata Pelajaran Gambar Teknik

Adanya perbedaan yang signifikan dari hasil belajar kognitif siswa pada kategori mata pelajaran gambar (Gambar Teknik) setelah diterapkan metode pembelajaran kooperatif Student Facilitator And Explaining terjadi karena dalam proses pembelajaran setiap kelompok berdiskusi dan mengemukakan pendapatnya di depan kelas tentang materi yang mereka diskusikan dengan kelompoknya. Apabila ada kelompok lain yang memiliki pendapat berbeda akan didiskusikan bersama dengan guru mata pelajaran untuk mendapatkan hasil diskusi yang tepat sesuai dengan tujuan pembelajaran.

Siswa dalam mengemukakan pendapat juga menjelaskan tentang materi dan mempraktikan cara penggunaan peralatan gambar teknik seperti kertas, penggaris, pensil dll di depan kelas. Kegiatan tersebut menuntut siswa untuk memahami materi tersebut sebagai tanggung 
jawab untuk menjelaskan kepada teman sekelasnya.

Dengan demikian selain mampu memperbaiki hasil belajar kognitif siswa penerapan metode pembelajaran kooperatif Student Facilitator And Explaining pada kategori mata pelajaran gambar (Gambar Teknik) juga memberikan kepercayaan diri siswa dalam berpendapat, saling menghargai pendapat sesama siswa dan tanggung jawab dalam menjelaskan hasil diskusi kelompoknya.

5. Perbedaan peningkatan nilai pretest ke post-test pada keempat kategori mata pelajaran produktif SMK Teknik Bangunan.

Keefektifan metode pembelajaran kooperatif Student Facilitator and Explaining memperbaiki hasil belajar ranah kognitif siswa pada keempat kategori mata pelajaran produktif SMK Teknik Bangunan dapat dilihat dari selisih nilai pre-test ke post-test, Hasil ini dapat dilihat pada gambar berikut :

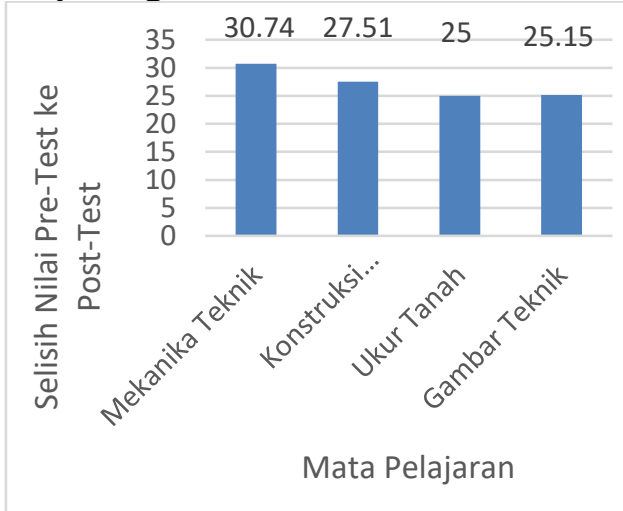

Gambar 8. Histogram Perbandingan Selisih Hasil Belajar Pre-Test dan Post- Test Ranah Kognitif Siswa Pada
Empat Kategori Mata Pelajaran Produktif SMK Teknik Bangunan

Gambar Histogram menunjukkan bahwa metode pembelajaran kooperatif Student Facilitator and Explaining paling efektif untuk memperbaiki hasil belajar ranah kognitif siswa pada kategori mata pelajaran hitungan (Mekanika Teknik) dengan peningkatan hasil belajar kognitif 30.74 dari nilai pre-test ke nilai post-test. Meskipun bukan nilai rerata yang paling tinggi dibandingkan kategori mata pelajaran produktif SMK Teknik Bangunan yang lain, tetapi selisih perbedaan yang signifikan nilai kognitif siswa pada kategori mata pelajaran hitungan (Mekanika Teknik) yang paling signifikan.

Peningkatan hasil belajar kognitif siswa setelah penerapan metode pembelajaran kooperatif Student Facilitator and Explaining paling efektif untuk memperbaiki hasil belajar ranah kognitif siswa pada kategori mata pelajaran hitungan (Mekanika Teknik) menjadi lebih baik dibandingkan dengan kategori mata pelajaran produktif SMK Teknik Bangunan yang lain.

Setelah pengamatan saat penelitian disebabkan karena sebelum penerapan metode pembelajaran kooperatif Student Facilitator and Explaining pada kategori mata pelajaran hitungan (Mekanika Teknik), anggapan siswa terhadap mata pelajaran hitungan adalah kategori mata pelajaran yang sulit sehingga motivasi siswa untuk belajar menjadi kurang. Berbeda dengan kategori mata pelajaran lain yang 
membuat siswa lebih termotivasi sebelum diterapkannya metode pembelajaran kooperatif Student Facilitator and Explaining, karenn a merupakan suatu hal baru untuk mempelajari praktik gambar maupun ukur tanah serta teori dasar konstruksi bangunan.

Saat diterapkan

metode pembelajaran kooperatif

Student Facilitator and

Explaining dalam proses

pembelajaran setiap kelompok berdiskusi dan mengemukakan pendapatnya di depan kelas tentang materi yang mereka diskusikan dengan kelompoknya. Apabila ada kelompok lain yang memiliki pendapat berbeda akan didiskusikan bersama dengan guru mata pelajaran untuk mendapatkan hasil diskusi yang tepat sesuai dengan tujuan pembelajaran.

$$
\text { Siswa dalam }
$$
mengemukakan pendapat juga menjelaskan tentang materi hitungan dan memecahkan masalah hitungan di depan kelas menuntut siswa untuk memahami materi tersebut sebagai tanggung jawab untuk menjelaskan kepada teman sekelasnya. Dengan demikian selain mampu memperbaiki hasil belajar kognitif siswa penerapan metode pembelajaran kooperatif Student Facilitator And Explaining pada kategori mata pelajaran hitungan (Mekanika Teknik) juga memberikan kepercayaan diri siswa dalam berpendapat, saling menghargai pendapat sesama siswa dan tanggung jawab dalam menjelaskan hasil diskusi kelompoknya.

\section{SIMPULAN}

Berdasarkan hasil penelitian yang dilakukan, dapat diambil kesimpulan bahwa terdapat perbedaan yang signifikan pada hasil belajar kognitif siswa dengan penerapan metode pembelajaran Student Facilitator and Explaining pada kategori mata pelajaran hitungan (Mekanika Teknik), kategori mata pelajaran teori (Konstruksi Bangunan), praktek (Ukur Tanah) dan gambar (Gambar Teknik).

Dapat diketahui juga pada kategori mata pelajaran produktif yang mendapat hasil belajar kognitif siswa yang paling baik setelah penerapan metode pembelajaran Student Facilitator and Explaining yaitu pada kategori mata pelajaran hitungan (Mekanika Teknik).

\section{SARAN}

Bagi Siswa, Siswa mengikuti langkah-langkah yang diinstruksikan saat dilaksanakan penelitian.

Bagi Guru, Metode pembelajaran kooperatif Student Facilitator and Explaining dapat dijadikan sebagai alternatif pembelajaran pada keempat kategori mata pelajaran produktif di SMK teknik bangunan yaitu kategori mata pelajaran hitungan (mekanika teknik), kategori mata pelajaran teori (konstruksi bangunan), kategori mata pelajaran praktik (ukur tanah) dan kategori mata pelajaran gambar (gambar teknik), sehingga melibatkan siswa dalam peran aktif saat proses pembelajaran dan mampu memperbaiki hasil belajar kognitif siswa. 
Bagi Sekolah, Sekolah sebaiknya memberikan sarana dan prasarana kepada guru untuk mengembangkan teknik pembelajaran yang kreatif dan inovatif sehingga hasil belajar siswa menjadi lebih baik, seperti buku pelajaran siswa sebagai media pembelajaran.

Bagi Peneliti Selanjutnya, Dalam penelitian ini hasil uji validitas, realibilita, daya pembeda dan tingkat kesukaran data serta dokumentasi masih lemah. Untuk peneliti yang ingin melanjutkan maupun mengkaji penelitian ini perlu memperhatikan prosedur yang benar saat melakukan uji validitas, realibilitas, daya pembeda dan tingkat kesukaran data serta dokumentasi yang lengkap agar mendapatkan hasil yang lebih baik.

\section{DAFTAR PUSTAKA}

Budiyono. (2015). Pengantar Penilaian Hasil Belajar. Surakarta: UPT UNS Press.

Budiyono. (2009). Statistika Untuk

Penelitian. Surakarta: UPT UNS Press.

Efendi, Agus. (2011). Hand Out Mata Kuliah Statistik di Bidang Pendidikan. Surakarta: Universitas Sebelas Maret.

Sims, R. and Demediuk, P. (1995). Student facilitators:

Maximising the outcomes from tutorial casework, literature analysis and problem solving. Perth: Edith Cowan University. Sugiyono. (2014). Metode Penelitian Kuantitatif, Kualitatif dan $R \& D$. Bandung: Alfabeta. UPT FKIP UNS, (2016). Buku Pedoman Penulisan Skripsi
FKIP Universitas Sebelas

Maret Tahun 2016 